\author{
Hanna Salich (iD \\ University of Warsaw \\ hanna.salich@uw.edu.pl
}

\title{
Authorial Neologisms in Translation: Is the Translator a Smuggler?
}

\section{Introduction}

The present paper focuses on the translation of selected authorial neologisms extracted from Stanislaw Lem's novel Pamiętnik znaleziony $w$ wannie, published for the first time in 1961 and translated into English by Michael Kandel and Christine Rose as Memoirs Found in a Bathtub more than a decade later [Stanisław Lem - The Official Site; Lem 1976].

A literary translator dealing with a science fiction novel has to be aware of certain linguistic obstacles that may emerge during the translation process. These obstacles are often closely related to the structure of the narrative world and to the borders set by the author. The first border is the one between the real and the fictitious. According to Zgorzelski, one of the basic assumptions in literary studies is that all narrative worlds are unreal [2004: 17]. Thus, the fictitious is not real even though the reader may sometimes experience a different feeling, a feeling that the narrative world depicted in a literary work bears some greater or lesser resemblance to reality, to what she or he knows from 
everyday life. According to Steiner [1975: 224, 227], this ability to create "alternities" through language, i.e. to invent "other worlds" and to tell "un-truths", is the greatest tool at a person's disposal because it helps to violate reality while being creative. It also enables the development of individual human beings and hence the entire human race:

We secrete from within ourselves the grammar, the mythologies of hope, of fantasy, of self-deception without which we would have been arrested at some rung of primate behaviour [...]. In the creative function of language non-truth or less-than-truth is... a primary device. [...] At every level, from brute camouflage to poetic vision, the linguistic capacity to conceal, misinform, leave ambiguous, hypothesize, invent is indispensable to the equilibrium of human consciousness and to the development of man in society [Steiner 1975: 227, 229].

In order to create an improbable setting and the unfamiliar features of a narrative world the author of literary work of science fiction has to set another type of border, the one between the fictitious (perceived as real) and the fantastic [cf. Zgorzelski 2004: 17]. In other words, she or he has to use the technique of defamiliarization (or ostranenie) - which, generally speaking, constitutes in "[making] the familiar seem strange" with the purpose of prolonging the readers' attention [Shklovsky 1917], in order to produce cognitive estrangement [Suvin 1979]. According to Shklovsky [1917], "The technique of art is to make objects 'unfamiliar,' to make forms difficult, to increase the difficulty and length of perception because the process of perception is an aesthetic end in itself and must be prolonged". According to Handke, the author may attain this goal in two complementing ways: the first one is to provide descriptions of a fantastic world, while the second is to give names to its fantastic elements. The latter possibility requires coining neologisms, combining words in an unprecedented way (new collocations and phrases), and using neosemes [Handke 1989: 233-247].

Finally, the third type of border emerges when a literary work needs to be translated into another language. In this case, the responsibility of a translator who removes the linguistic barrier is twofold: she or he has to bridge the border between the source and target reader by rendering the sense and form of the original while at the same time preserving the borders set by its author. This brings us to the question whether neologisms, which according to Newmark [1988: 140] cause translation problems for all translators, can be translated faithfully in terms of form and 
meaning. Newmark [1988: 143] claims that these two features, as well as the sound-effects neologisms may produce, not only can but should be reproduced faithfully in the target language. In order to satisfy this principle, one should invent target language counterparts that consist of "the same or equivalent morphemes" or of phonemes that reproduce the sound-effect intended by the author [Newmark 1988: 143]. Newmark also claims that "in a literary text, it is [the translator's] duty to re-create any neologism he meets on the basis of the SL neologism" [Newmark 1988: 149; my italics]. Accordingly, Newmark strongly opts for preserving the formal features of neologisms in literary translation, leaving hardly any space for other solutions, such as translating a neologism with a non-neologism, which according to Krajewska [Chomik and Krajewska 2011: $186]$ is sometimes practiced by literary translators and even acceptable under certain circumstances. The phrase "on the basis of the SL neologism", however, offers some translation freedom as Newmark does not clearly state that the TL neologism should reproduce the exact type of the SL neologism, or be recreated in an analogous word-formation process. According to Hejwowski [2009: 113], recreating literary neologisms in this way is possible, which he illustrates with several examples. Interestingly, the scholar points out that the principle according to which one should translate an SL neologism with a TL neologism cannot always be obeyed, as it may result in unnatural sounding equivalents; however, he underlines that Newmark's approach should be followed whenever possible [Hejwowski 2009: 113-114]. One may therefore conclude that a literary translator might in fact face a situation in which rendering both sense and form of an authorial neologism will turn out to be impossible. Another conclusion could be that in such cases, it is the naturalness of expression rather than the formal features of a neologism that need to be preserved. Accordingly, the translator should attempt to achieve Nida's formal equivalence, while remembering that it does not always have to be strict [Nida 2000: 130]. Hence, in case direct translation procedures, the use of which favours achieving formal equivalence, should threaten the naturalness of expression, the translator may resort to oblique translation procedures in order to provide appropriate equivalents. On their list of translation procedures, Vinay and Dalbernet [2000: 85-91] mention three direct procedures: literal translation, calque, and borrowing, and four oblique procedures: transposition, modulation, equivalence, and adaptation. In this paper, however, the term "direct procedures" refers to 
translation solutions rendering both formal and semantic features of authorial neologisms, while the term "oblique procedures" encompasses all other solutions aside from the extreme translation technique of omission. Hence, the term "oblique procedures" used in this paper includes additions and instances of compensation.

\section{The two worlds of Memoirs...}

The author of Memoirs Found in a Bathtub did not limit himself to just one narrative world but created two of them: the fantastic world of the future, the existence of which is only signaled in the Introduction, and the fictitious world of the past (perceived by the reader as contemporary) depicted in Notes from the Neogene, which follows the Introduction. Accordingly, the novel presents two borderlands: a fictitious narrative world (which despite being peculiar and even absurd still seems probable and familiar) and a fantastic one (which is intended to be the opposite and evoke a strong effect of estrangement).

As far as the content of the Introduction is concerned, a civilization of the future finds memoirs written by a human who lived in what they perceive as "Neogene". This archaeological find, found in a bathtub situated in the "Pentagon of the Last Dynasty" of "Prexy-dents" also known as "Prez-tendz", is of historical value for at least two reasons. First, it was written on "papyr", which, as described by the author,

was whitish, flaccid, a derivative of cellulose, rolled out on cylinders and cut into rectangular sheets. Information of all kinds was impressed on it with a dark tint, after which the sheets were collated and sewn in a special way [Lem 1976: 5].

Moreover, "papyr" used to be an extremely significant artefact:

not only did papyr regulate and coordinate all group activities, but it determined, in some obscure way, the fate of individuals (for example, the 'identity papyrs')... In that era one could not be born, grow up, obtain an education, work, travel, marry or die except through the aid and mediation of papyr [Lem 1976: 7].

At some point, however, a cataclysm took place and led to the destruction of "papyr". This cataclysm, referred to as "papyralysis", was presumably caused by "some papyrophagous microbe" and originated in "enormous 
data storage centers called li-brees" situated in "the lost land of Ammer-Ku" [Lem 1976: 10]. The ancient civilization could not manage the crisis and entered into the period called "the Chaotic", which lasted two hundred years and remains a mystery, "for even chronotraction methods have failed to provide the most fundamental details of the social life at that age" [Lem 1976: 10]. Also making Notes of historical importance (from the perspective of the future civilization) is the fact that it is the "last message from the Neogene, the Era of Papyrocracy" [Lem 1976: 16].

As for the plot of Notes, a nameless protagonist finds himself inside a Building. He is given a Mission but is left without details that would enable him to complete it. Thus, he tries to obtain the missing information by wandering around the Building, where he visits various places and meets people whose behaviour is, to say the least, bizarre. Strange events take place during his search for the Mission's details, as the Building is full of agents, people communicate using codes, and nothing is as it seems to be.

It is worth mentioning at this point that the Introduction does not function as introductions usually do. To be more specific, it contains no background information aimed at facilitating the process of reading. Moreover, it is impossible to skip it because the Introduction sets the rules of the narrative world. In fact, the Introduction is supposed to make the reading easier for the imaginary recipient of the future, and as such it becomes bizarre to the actual reader. A similar pattern can be observed in the case of Notes: its content is supposed to be troublesome to the imaginary audience invented by the author, but they turn out to be much more familiar (though still bizarre) to the actual reader than the very introduction itself.

The above plot descriptions show that the Introduction, which is an attempt at reconstructing a reality unknown to the imaginary audience of the future, contains numerous deformed words (Prexy-dents, Prez-tendz $<$ presidents, papyr $<$ paper, li-brees $<$ libraries, Ammer-Ka $<$ America). Some of them constitute a word-formation base for other neologisms ( $p a$ pyralysis, papyrophagous, Papyrocracy < papyr), which form untypical collocations (papyrophagous microbe) and phrases (the Era of Papyrocracy). The Introduction contains also old words with new meanings (the Neogene) as well as lexical inventions such as chronotraction, which suggests technological advancement known to the imaginary audience but unfamiliar to the actual reader. All such neologisms signal the existence of an imaginary world of the future and, interestingly, their frequency is 
very high as the approximately (depending on the edition) 12-page long Introduction contains about 100 neologisms of various kinds.

It is worth noting that the plot of Notes, unlike the plot of the Introduction, can be summarised without using any neologisms. This does not mean, however, that they are absent from this part of the work; it may, though, suggest that the new vocabulary occurs less frequently than in the previous case, perhaps because Notes offers a seemingly naturalistic storyline. The plot description may also indicate that the new vocabulary is related to people and places.

\section{Authorial neologisms in Memoirs...}

As already mentioned, authorial neologisms belong to the methods of creating fantastic realities. Depending on their structure, they can be divided into one-word neologisms (absolute and structural ones) and multipleword neologisms (collocational and phrasal ones, which may be composed of common words or one-word neologisms or be a combination of the two). Another type of coinage is a neoseme, a common lexical item that has changed its meaning within the context of a literary work; like one-word neologisms, neosemes may constitute a part of multiple-word neologisms. The above typology is based on classifications by Handke [1989: 228- 248], Hejwowski [2009: 112], Stockwell [2000: 109-120], and Chomik and Krajewska [2011]; these typologies do not mention mixed neologisms, though.

The structure and the shifts in meaning, however, are not the only criteria for classifying coinages, as authorial neologisms which denote new elements of a fantastic narrative world may be also grouped thematically. Hence, the source text (ST) neologisms that appear in Memoirs Found in a Bathtub can be divided into two large groups, appellative and onomastic (classification adopted from Krajewska [2011] and Domaciuk [2003]). Since the Introduction and Notes present two different realities, one may expect these "brave new words" (as Prucher [2007] calls SF neologisms) to denote different sets of elements. Accordingly, the appellative ST neologisms found in the Introduction refer to historical periods (archeocredon), artifacts (papyr), scientific disciplines (astrogacja pierwotna), and achievements of the future civilization (gnostron); the ST onomastic neologisms from the Introduction name people (Ser Een), places (Ammer$\mathrm{Ku}$ ), institutions (Instytut Temporystyki), historical buildings (Pentagon), 
and gods (Thoo-Llar). The ST appellative neologisms of Notes, in turn, refer to military men (admiradier), chaplains (oficer spowiednik), agents (trzeciak), military operations (operacja Gwózdek), decorations (Order Tajnego Stopnia), devices (podstuchowa grzalka do herbaty), mental disorders (drżaczka wielowywiadowcza), rooms (sekcja ruchu dusz), book sections in a library (wnętrzarstwo), and disciplines (agonalistyka). Moreover, some of the ST appellative neologisms of Notes are derived from common nouns, such as gmach (building) and agent (agent). The examples of such neologisms include gmaszystość and agenturalia. The onomastic neologisms of Notes indicate people (Blanderdash), with one exception: the ST neologism DESZ, an abbreviation of the word deszyfrator (deciphering device), refers to a machine.

\section{The analysis}

The set of examples presented above by no means covers all the authorial neologisms to be found in the novel. As the literary work under investigation contains vast numbers of lexical inventions which can be categorized in a number of ways, it was necessary to create a database of ST neologisms accompanied by their target text (TT) counterparts in order to examine how the translators dealt with the task of bridging and preserving the borders discussed above.

The analyzed sample comprised approximately 300 ST authorial neologisms (43 onomastic and 63 appellative neologisms from the Introduction as well as 37 onomastic neologisms and 127 appellative ones from Notes) of various types and their TT equivalents. Since the data were intended to include neologisms and their English counterparts, the sample could not contain some of the neologisms that do not have one-to-one equivalents, such as coinages that occur in accumulation - these were analyzed outside the database, and we shall comment on them as they provide interesting observations - or in titles, which are specific translation items even if they contain no neologisms [see Hejwowski 2004: 167-183]. Moreover, the database did not include neologisms that do not name elements of fantastic reality (and these were mostly omitted in translation).

Before we proceed to the results of the analysis, it seems inevitable to discuss some of the excerpts excluded from the database, those overloaded with authorial neologisms. The following excerpt comes from an 
imaginary encyclopaedia for spies; the entry aparaty inwestygacyjne (literally "investigation devices") lists torture equipment:

(...) patrz: APARATY INWESTYGACYJNE. Poszukałem tych aparatów i znalazłem cały spis, zaczynający się od wyliczenia dziwnych jakichś maszyn, jak ćwiartolet, lamignatnica, zaskórzacz, wmóżdżacz, inaczej INCEREBRATOR PRAWDY OSTATECZNEJ (...) [Lem 2000: 91].

(...) see THIN AIR, POWDER, LAMB. Then there was a whole list of odd items under DECEREBRATION: persuasion by quartering, screws for screws, breaking codes without bones, fundamental flaying, and so forth [Lem 1976: 79].

As it is clearly evident, the original form of the source text elements was not preserved in translation. Also, their sense was modified: ćwiartolet, tamignatnica, zaskórzacz, wmóżdzacz seem to be the names of devices (where the first is used for quartering, the second for breaking bones, the last two for inserting something under one's skin or inside one's brain respectively), whereas persuasion by quartering, screws for screws, breaking codes without bones, fundamental flaying may be the names of methods. Moreover, it is almost impossible to call screws for screws an equivalent of any of the four devices (it may stand only for wmóżdzacz as the remaining equivalents are semantically similar to three other ST neologisms). The excerpt also suggests that incerebrator prawdy ostatecznej (literally "absolute truth incerebrator") is a synonym of wmóżdzacz; no such synonym is present in the target text and the word "decerebration", which seems to share some semantic features with the ST neologism, evokes different connotations. Hence, if such modifications (concerning the form and meaning) occur in the "attention-catching" passages overloaded with neologisms, one may expect that similar translation solutions have also been applied elsewhere.

The following example shows that the translators coined new neologisms and added elements that are absent from the ST:

Średniowiecze znało szpiegarnie, także śpiegarnikami zwane. W obcych językach szpik, espion, espionizm, kierunek artystyczny, ciekawy bardzo [Lem 2000: 179]. 
In the Middle Ages we have spyeries, espyals. To spy, spionieren, spitzeln, espionner, skopiao, szpiegowac, spijunirati... Treason, tresun, treysoun, tradere, trahison... [Lem 1976: 152].

The above excerpt contains five neologisms, three structural (szpiegarnie, śpiegarniki, espionizm) and two semantic (szpik, espion). Its translation, in turn, contains three neologisms (spyeries, espayals and skopiao), seven borrowings from German (spionieren, spitzeln), French (espionner, trahison), Polish (szpiegowac), Serbian (spijunirati) and Latin (tradere), as well as archaic Middle English and Anglo-French forms of the common noun "treason" (tresun, treysoun).

In the case of excerpts similar to that presented below (i.e. containing additions, considerable semantic modifications and word reordering), it is difficult to match the ST neologisms to their TT equivalents; hence, those elements were excluded from the database:

...dziwne terminy, jakieś zapadnie-double, szyfrokłódki, więcierze i apertury ryglowe, supercuhalty wielokrotne, wniki zamczyste, cielesne nadzienia... [Lem 2000: 96].

...this barrage of strange terminology - triple tails, coded leaks, spotted caches, exposed plants, strategic lays, integrated risks, sensitive channels, high-grade rendezvous entrapment... [Lem 1976: 83-84].

Matching ST neologisms to their TT equivalents becomes even more complicated in the case of excerpts comprised almost entirely of neologisms, such as the text of a message that underwent the decoding process, resulting in:

Baremisozyturia inpeklancybilistyczna matetosi się by kancepudroliwać ambrendafigianturelię nieodkocywracipośmajną... [Lem 2000: 75].

BABIRUSANTOSITORY IMPECLANCYBILLISTIC MATOTEOSIS AIN'T CATACYPTICALLY AMBREGATORY NOR PHAROGRANTOGRAPHICALLY OSCILLUMPTUOUS BY RETROVECTACALCIPHICATION NEITHER... [Lem 1976: 65-66].

From the above examples one may conclude that the translators allow themselves much freedom while rendering authorial neologisms into English. However, the analysis that follows proves otherwise. 
The objective of the analysis of the Polish and English versions of the novel was to examine what happens to authorial neologisms in translation, whether they "cross the border" or not, and whether the translators incline more towards preserving their sense or their structure.

The analysis of the Introduction reveals that the equivalents contrasted with the corresponding ST items have the following characteristics:

1. the same form and very similar sense $(64 \%)$,

2. the same form and modified sense (19\%),

3. different form and very similar sense $(10 \%)$,

4. different form and modified sense (5\%),

5. omission $(2 \%)$.

Accordingly, the neologisms belonging to the first (and the largest) group may be said to have fully "crossed the border". In other words, they have retained their original sense and form of structural neologisms (bao-blyo-theki-li-brees), neosemes (neogen - Neogene), collocational neologisms (elektryczny mózg - electronic brain), collocational neologisms containing a structural neologism (papyr osobisty - identity papyr) or a neoseme (późny neogen - Late Neogene). Retaining both these features is a result of using the technique of literal translation and its variant that consists in translating a base word literally and deforming it in an analogous way (biblioteki $>$ bao-blyo-theki $>$ libraries $>$ li-brees). The above examples show also an instance of transfer (papyr). Hence, direct translation procedures may lead to preserving the intended meaning of a neologism and to preserving its type in translation.

The second group comprises neologisms that have retained their form (and thus their fantastic properties) but not the exact meaning. The meaning expressed by the TT neologisms, however, shows a certain degree of resemblance to the meaning of the ST neologisms. For example, the structural neologism papyroliza was translated faithfully as papyralysis. One element was transferred (papyr) and the other (-liza) translated with its typical equivalent (-lysis). The only element that underwent modification is the interfix (-o- into $-a-)$. This seemingly minor intervention resulted in a change of connotations: the neologism papyroliza makes the Polish reader think of disintegration, whereas the equivalent papyralysis brings to mind the word "paralysis". A similar situation may be observed in the case of the structural neologism baun-knooty (derived from the word banknoty - banknotes) translated as cheks (a structural neologism resulting from an intentional misspelling in the word checks), a collocational 
neologism with a structural neologism zarazek atakujacy papyr (literally "a germ that attacks papyr") translated as papyrophagous microbe (a microbe that eats papyr), and so forth. In the case of papyralysis, which is an instance of literal translation combined with transference, the modification of meaning was unavoidable. Hence, the meaning may be subject to modification even if the TL neologism contains equivalent morphemes. The two remaining modifications seem to result from a deliberate decision to provide a neologism based on a cultural equivalent (cheks < checks) and a neologism that sounds more natural than the literal translation of the SL one (papyrophagous microbe instead of "a germ that...").

Within the third group - comprising the TT neologisms that differ from their ST counterparts in form but have almost identical meaning we can observe several interesting translation patterns, where the collocational neologisms containing a structural neologism are replaced with one of the following items:

a. structural neologism, e.g. czasy chaotyckie (literally "chaotic times") - the Chaotic (a TT neologism resulting from zero-derivation),

b. collocational neologism, e.g. okres galaktyjski - Galactic Period (which is a literal translation),

c. neoseme + collocational neologism with a structural neologism, e.g. neogeniczna epoka papyrowa (literally "papyr age of Neogene") the Neogene, the Era of Papyrocracy,

d. phrase containing a collocational neologism, e.g. czasochłony satelitarne Księżyca (literally "time-absorbers that orbit the Moon") time wells that orbit the Moon,

e. collocation (lacking fantastic properties), e.g. zbiornice wiedzonośnych papyrów (literally "collecting centers of knowledge carrying papyrs") - data storage centers.

As can be seen from the above examples, structural neologisms tend to be replaced with collocational neologisms and, consequently, lose some of their fantastic properties.

The fourth group of equivalents, those with a different structure and modified (yet similar) sense, includes the cases of translating collocational neologisms containing a structural neologism with structural neologisms, e.g. chronosonda wsteczna (literally "retrograde chronoprobe") chronotraction, and replacing structural neologisms with common nouns, e.g. kataczynnik - catalyst, or collocational neologisms, e.g. czasowiercenie (literally "time drilling") - time delving. 
As far as the group of "missing equivalents" is concerned, there was only one instance of omission, exemplified by the ST neologism aphisse, which is similar to the word afisze (posters, bills) and refers to a "neogenic", papyr-related artifact.

A simplified data arrangement (in which we do not look at the abovementioned combinations but only at what is preserved in the target text) reveals that the English translation is sense and structure oriented. Accordingly, sense-preserving translation techniques constitute $98 \%$ of all the techniques, wherein $74 \%$ of them produce equivalents with meanings almost identical to those of their ST counterparts, 24\% have modified but similar meanings, and the remaining $2 \%$ are omissions. The percentage of structure-preserving techniques amounts to 95 (84\% of the equivalents have the same structure as their ST counterparts, $11 \%$ have different structure but are still neologisms), $3 \%$ of the equivalents are common words, and the remaining $2 \%$ are omissions.

The analysis of the Notes reveals that the equivalents of the analyzed authorial neologisms are more diversified than those from the Introduction; the characteristics of the equivalents can be described as follows:

1. the same form and very similar sense $(29 \%)$,

2. the same form and modified sense (11\%),

3. the same form and different sense (5\%),

4. different form and very similar sense $(23 \%)$,

5. different form and modified sense (13\%),

6. different form and different sense $(5 \%)$,

7. omission (14\%).

In order to avoid repetition, we shall now concentrate on the groups of equivalents which have not yet been discussed (the third and the sixth) and provide additional observations on the remaining groups if necessary.

The third group of equivalents comprises the entities which have retained their original form within the translation process but are far from being equivalent to their ST counterparts as far as meaning is concerned. The examples include structural neologisms, such as gmachoznawstwo (literally "edificistics") - Nanosemy, and collocational neologisms like sekcja ruchu dusz (literally "soul motion section") - Holy Spirit Section.

The fourth group of equivalents, which when contrasted with the ST neologisms differ in form but share their meaning, may be divided into the two subgroups of neologisms and non-neologisms. The subgroup of non-neologisms (absent from the corresponding group of equivalents 
from the Introduction) comprises structural neologisms translated with phrases (gmachowiec - one of us), collocations (gmaszystość - Building's nature), common words (admiradier - admiral), collocational neologisms translated with common words (oficer instrukcyjny-guide) and neosemes translated with common words (podstuchowy-Eavesdropper). As can be seen from these examples, the equivalents no longer have fantastic features; hence, they do not produce cognitive estrangement.

The fifth group of equivalents (the structure of which was changed, and the sense modified) also contains non-neologisms, the use of which while translating SL neologisms leads to translation losses. The loss of fantastic properties within the translation process is exemplified by the following translation patterns of changing neologisms of various types into common words or phrases:

a. structural neologism > common word, e.g. brygandier (coined from the word brygadier that stands for "brigadier") - General,

b. collocational neologism with a structural neologism $>$ phrase, e.g. celer lawy oskarżonych (the context does not explain the meaning of the neologism celer, but this is someone related to the dock in a courtroom) - the defendant in court,

c. collocational neologism with a structural neologism $>$ common word, e.g. sala Degradancji i Dekorancji (a name of a room where demotion and decoration take place) - Degrading,

d. collocational neologism > common word, e.g. Sekcja Zdawcza Dziennika Podawczego - Registry,

e. collocational neologism > phrase, e.g. kazuistyka zdrady (literally "casuistry of treason") - Anatomy of Treason.

The sixth group of equivalents, which differ from ST neologisms in terms of structure and meaning, reveals the following translation patterns:

a. collocational neologism with a structural neologism $>$ collocational neologism, e.g. drżączka wielowywiadowcza (literally "multiespial shivers" $)$ - top priority hysteria,

b. neoseme $>$ structural neologisms, e.g. desemantyzacja (desemantisation) - Nanosemy, Demisemiotics,

The word "multiespial" is a structural neologism coined for the purposes of this paper with an intention to show the semantic difference between the possible literal translation and the actual equivalent. 
c. collocational neologism > common word, e.g. oficer instrukcyjny (discussed above) - spy,

d. structural neologism $>$ common word, e.g. infiltrator (someone preoccupied with infiltration) - sabotage.

The last group is that of omissions. The omitted neologisms were of various types, such as structural neologisms (agenturalia, which probably refers to espial-related objects), neosemes (trzeciak, which normally stands for a third-grader but within the novel refers to a triple agent), collocational equivalents (oficer spowiednik, which could have been translated literally as "officer-confessor"), and collocational neologisms with a structural neologism (pragmatyka zdradziectwa, which could have been translated as "pragmatics of treason"). As mentioned before, omission is an extreme technique of translating neologisms. It should be particularly avoided in the case of "key neologisms" such as agenturalia derived from the word "agent", which, similarly to the word "gmach", is a base of numerous neologisms in the ST. Moreover, by using this technique - which similarly to the technique of replacing neologisms with non-neologisms, consists in eliminating fantastic words from the TT - a translator reduces the estrangement effect intended by the author.

In brief, the translation of Notes is oriented more towards sense than structure. Accordingly, the percentage of the sense-preserving translation techniques amounts to 77 (53\% of the equivalents are almost identical to their ST counterparts in terms of meaning, while the sense of the remaining $24 \%$ was modified but shows some resemblance to the original). Moreover, the meaning of $9 \%$ of the equivalents is different than the meaning of the ST elements; omissions constitute $14 \%$ of cases. Contrastingly, the structure-preserving translation techniques constitute $66 \%$ of all the techniques ( $46 \%$ of the equivalents have identical structure as their ST counterparts; $20 \%$ have different structure but are still neologisms). As far as the remaining $34 \%$ of the equivalents are concerned, $14 \%$ were lost in translation and 20\% were translated with non-neologisms.

Hence, the analysis reveals that authorial neologisms are subject to translation losses, which negatively impact the strength of the estrangement effect by violating the borders set by the author. Interestingly, the number of these losses depends on the specificity of the fantastic narrative world. In the Introduction, which presents the reader with a world much more peculiar than that described in Notes, 60 out of the 63 analyzed appellative neologisms and all the onomastic neologisms were preserved in 
the target text (the latter were mostly transferred). In the case of Notes, the same happened to only 83 out 127 appellative neologisms and 35 out of 37 onomastic neologisms. However, the missing equivalents may be restored somewhere else within the target text, and such a possibility is offered to a translator by all the source text fragments overloaded with authorial neologisms (such as those excluded from the database). Hence, the additions that may occur in target versions of such fragments are probably instances of compensation in place [cf. Hervey and Higgins 1995: 29] rather than manipulation aimed at beautifying the original [cf. Hejwowski 2009: 114-115].

\section{Conclusions}

The dichotomy between the real and the fictitious allows treating the narrative and the actual world as two separate but constantly intermingling realities, as parallel universes, as two borderlands. The dichotomy between the fictitious, which shows resemblance to the real world, and the fantastic may lead to the emergence of additional borderlands, including ones existing within the literary work (which is the case with Memoirs Found in a Bathtub). The very necessity of translating a piece of literature can, in turn, be seen not only as an "operation" - to put it in Wojtasiewicz's terms - of bridging the border resulting from the linguistic and cultural differences existing between the source and target recipients, but also as an act of preserving the borders that result from the creative activity of an author. In order to achieve both, a translator of a science fiction literary text should follow Newmark's principle whenever possible. By doing so she or he will be able not only to preserve the meaning and the aesthetic effect produced by single authorial neologisms but also to recreate the estrangement effect.

The estrangement effect is notably stronger if a literary text contains numerous neologisms. Interestingly, not all science fiction texts can be said to possess this feature, which is because authors may prefer to defamiliarize the reality they depict by providing descriptions. Hence, some science fiction texts will contain as many as hundred neologisms, while other will contain just a few. This claim also holds true for separate parts of a single literary work, such as Introduction and Notes discussed above. Another feature influencing our perception of the fantastic narrative world and the estrangement effect is the density of authorial neologisms. 
In the analyzed novel, this density is considerably greater in the Introduction. Interestingly, the Introduction is also a fragment of the novel which was translated more faithfully. Notes, which presents a world closer to our everyday experience, is, by contrast, characterized by much lower density of authorial neologisms. This density is even lower in the target text, as numerous one-word and multiword coinages lost their fantastic properties within the translation process (they were either omitted or replaced with non-neologisms). The above observations prove that Guttfeld's claim [2008: 353], according to which fidelity to the original depends upon the specificity of the narrative world, is applicable not only to the translation of culture-bound items (which she deals with) but also to the translation of authorial neologisms. Hence, the formal equivalence of authorial neologisms [see Hejwowski 2009: 112-113] is probably to be observed more often in translations of highly defamiliarized science fiction texts.

Returning to the estrangement effect, neologisms produce it with various degrees of strength depending on their structure (the less familiar the neologism, the stronger the effect) [cf. Handke 1989: 233-244], which is another argument in favour of preserving the formal features of SL neologisms in the TT. However, preserving them does not always go in hand with preserving the semantic features of authorial neologisms. Accordingly, the majority of neologisms in the Introduction were translated with the preservation of their sense and structure, i.e. the translators recreated not only their meaning but also their original types. Sometimes, however, they resorted to using oblique translation methods, which resulted in preserving the form but modifying the sense, preserving the sense but modifying the form, or changing the form and modifying the sense. The use of oblique translation methods is, as suggested above, even more vivid in Notes. Like the neologisms in the Introduction, the majority of neologisms in Notes reproduce both the form and meaning of the SL neologisms. However, the percentage of neologisms translated this way is half than those found in the Introduction. At the same time, we may observe more instances of omissions. The results of using oblique translation methods are more varied than in the Introduction, as they also include preserving the form while changing the sense and changing the form while modifying the sense. A detailed analysis of the selected examples shows that naturally-sounding and fully acceptable neologisms, such as papyralysis or a papyrophagous microbe, recreated on the basis of the SL neologism, i.e. with observance to the Newmark's principle concerning 
the translation of literary neologisms, may evoke new connotations absent from the ST but legitimate in the context of a literary work. Moreover, there is a tendency to replace structural neologisms with collocational ones, which reduces the estrangement effect. This is because collocational neologisms compared to structural ones are perceived by the reader as more familiar [cf. Handke 1989: 234, 243-244]. The estrangement effect is not preserved when translators decide to violate Newmark's principle and replace a neologism with a common noun, collocation or phrase. In other words, the tendency to normalize or eliminate fantastic authorial neologisms causes translation losses and changes the effect intended by the author. According to As-Safi and Ash-Sharifi [1997], "the translator should endeavour to neologize to enhance literary effect, or to compensate for loss of effect elsewhere in the text where he has been unable to render an SL neologism by a TL neologism". Fortunately, the passages overloaded with neologisms offer translators a possibility to compensate for these losses by "smuggling in" (adding) their own neologisms. This kind of addition is similar to Harvey and Higgins' compensation in place [1995: 29]; it is also similar to Vinay and Dalbernet's adaptation [2000: 91], but only in the sense that it passes unnoticed to the target recipient, who accepts it as natural. Hence, adding a neologism in such a passage of the TT may be viewed as an oblique translation procedure even though Vinay and Dalbernet [2000] do not list addition as such (in fact they do not distinguish this procedure at all). At the same time, the opportunity to coin one's own neologism in such a way, that is without being restricted by the SL structures, is a rare case in which one may exercise full translation freedom. As far as the loss of estrangement effect produced by a specific type of neologism is concerned, a translator may also apply a technique that could be referred to as "compensation in type", as it consists in replacing a more familiar neologism with a less familiar one, such as replacing a collocational neologism with a structural one.

As for the question stated in the title, a translator who struggles to preserve as many features of the authorial neologisms as possible may sometimes act as a smuggler in order to compensate for the unavoidable translation losses. Most of the time, however, she or he is a mediator between the author of the original and his or her target-language audience. 


\section{REFERENCES}

As-Safi, Ash-Sharifi (1997), "Naturalness in Literary Translation", Babel, 43(1), pp. 60-75, https://doi.org/10.1075/babel.43.1.05ass.

Chomik, M., Krajewska, M. (2011), Od nominacji do kreacji. Rzecz o przekładzie neologizmów science fiction, Wydawnictwo UMK, Torun.

Domaciuk, I. (2003), Nazwy własne w prozie Stanisława Lema, Wydawnictwo UMCS, Lublin.

Guttfeld, D. (2008), English-Polish Translations of Science Fiction and Fantasy, Wydawnictwo Naukowe GRADO, Torun.

Handke, R. (1989), "Językowe sposoby kreowania składników fantastycznych", in: R. Handke, L. Jęczmyk, B. Okólska (eds.), Spór o SF. Antologia szkiców i esejów o science fiction, Wydawnictwo Poznańskie, Poznań, pp. 228-248.

Hejwowski, K. (2004), Translation: A Cognitive-Communicative Approach, Wydawnictwo Wszechnicy Mazurskiej, Olecko.

Hejwowski, K. (2009), Kognitywno-komunikacyjna teoria przekładu, PWN, Warszawa.

Hervey, S., Higgins, I. (1995), Thinking German Translation, Routledge, London-New York.

Lem, S. (2000), Pamiętnik znaleziony $w$ wannie, Wydawnictwo Literackie, Kraków.

Lem, S. (1976), Memoirs Found in a Bathtub, (translated by M. Kandel, Ch. Rose), Avon Books, New York.

Newmark, P. (1988), A Textbook of Translation, Prentice-Hall International, London-New York.

Nida, E. (2000), "Principles of Correspondence", in: L. Venuti (ed.), The Translation Studies Reader, Routledge, London-New York, pp. 126-140.

Prucher, J. (2007), Brave New Words: The Oxford Dictionary of Science Fiction, Oxford University Press, Inc., New York.

Shklovsky, V. (1917), “Art as Technique”, [online:] https://warwick.ac.uk/fac/ arts/english/currentstudents/undergraduate/modules/fulllist/first/en122/lecturelist-2015-16-2/shklovsky.pdf - 14.01.2019.

Stanisław Lem - The Official Site, [online:] http://english.lem.pl/works/novels $-10.06 .2018$.

Steiner, G. (1975), After Babel, Oxford University Press, London.

Stockwell, P. (2000), The Poetics of Science Fiction, Pearson Education Limited, Harlow, England. 
Suvin, D. (1979), "The State of the Art in Science Fiction Theory: Determining and Delimiting the Genre", [online:] https://www.depauw.edu/sfs/backissues/17/suvin17.htm - 4.01.2019.

Vinay, J-P., Dalbernet, J. (2000), “A Methodology for Translation”, in: L. Venuti, ed. The Translation Studies Reader, Routledge, London-New York, pp. 84-93.

Wojtasiewicz, O. (1957), Wstęp do teorii tłumaczenia, Zakład im. Ossolińskich, Wrocław-Warszawa.

Zgorzelski, A. (2004), Born of the Fantastic, Wydawnictwo Uniwersytetu Gdańskiego, Gdańsk.

\section{Abstract}

Science fiction depicts worlds that often differ greatly from the real one. These worlds may be set in the remote future and so consist of elements unfamiliar to the reader. The names of those elements may be untypical or, conversely, they may be typical but denote unexpected referents. However, the border between a fictional world (even the most fantastic one) and reality is not as thick as it seems to be. A similar relation exists between the original and target texts.

The article deals with Stanisław Lem's neologisms that occur in his novel Memoirs Found in a Bathtub and their translation into English. The real and literary world are understood as two borderlands and translation is viewed as creating a third one. The border is set by the author who, in order to separate the real from the fantastic, uses new words and expressions to name the elements of the narrative world. The translators, whose intention is to supply the text to the target reader, decode and render these names in various ways, and by doing so often change the shape of a given border.

Keywords: neologism, authorism, translation techniques, science fiction, literary translation 